\title{
Government and information - the limits of law's empire
}

\author{
by Patrick Birkinshaw
}

"Law's empire" is most readily associated with Ronald Dworkin's famous book. At the conclusion, Dworkin describes how an interpretation of law based on pure integrity seeks reform of law to achieve a "vision of social justice". There is an element of that aspiration in what follows. But my use of 'Law's Empire' is more prosaic. I am looking at the difficult areas where law - meaning judicial and constitutional control via the courts - has little role to play in government's use of information.

$\mathrm{H}$ aving just written a book entitled Government and Information published by Tottel Publishing it may appear a little strange to juxtapose that title with the limits of law's empire. Even the most perfunctory examination of the book will reveal a mass of legal duties and obligations in relation to information. That's why I first wrote it over 15 years ago. It followed on from another work I had written on Freedom of Information: the Law, the Practice and the Ideal (now 3rd ed, 2001) which is an academic monograph. I was informed by the secretary to the Hutton Inquiry that Freedom is standard introductory fare for civil servants coming into freedom of information.

This article's title addresses the relationship between government and information and the use of laws and other constraints to regulate access to information and protection of information. I want to explore the extent and limits of law in making government more open, more transparent. We have a Freedom of Information Act, Data Protection Act, Access to Environmental Information Regulations and most recently the Re-use of Public Sector Information Regulations (EIR). Public Records legislation has existed since the 1950s. Thousands of legal provisions provide for access to information or secrecy: sometimes both. Over 50 states have FoI legislation (including Zimbabwe - an act which I am informed is really a control of the press act: McDonald 2006). The EU has provisions based on a Treaty article and a regulation and not purely internal rules of procedure. The EU constitution would have strengthened the access provisions making them both constitutional and fundamental rights. Indeed, FoI has become a global pre-occupation but we do not have global FoI laws.

We seem to have a constant obsession in the UK with abuse by government of its powers. There have been Thatcher's excesses, the Judge over your Shoulder (1987) written in a churlish tone to advise civil servants on how to make their behaviour judicial review proof, and Blair's war and his obsession over the information and publicity machine at the heart of government leading to three inquiries into government's use of intelligence, officials and communications within 12 months (Hatton HC 247 (2003-04) Butler Cm 6942 and Phillis 2004 (Birkinshaw 2005 ch.2)). FoI was a means of bringing government closer to the people and Blair's government published their plans in December 1997. The story of what followed has been described elsewhere (Birkinshaw 2001 and 2005, Birkinshaw and Parkin 1999). And yet, despite a proliferation of access laws throughout the world, there has been an increased tendency to secrecy in the USA and in the UK - most evident in homeland security and the war on terror.

The worldwide experience of FoI laws is not always positive. I am an author of one of the essays in a stimulating book edited by Christopher Hood on Transparency to be published under the auspices of the British Academy in 2006. In the company of very distinguished social scientists, philosophers and public servants I am the sole lawyer. In his concluding chapter Hood emphasises that Birkinshaw alone makes the case for access to information as a human right. The image came to mind of some star gazing, wild-eyed libertarian - irresponsible and naïve. A good deal of criticism if not scepticism suffuses some of the essays in their analysis of the phenomenon of transparency and its modern instantiations.

The tone was set recently by Onora O'Neil in her Reith lectures in 2002 on A Question of Trust where she argues that our addiction to transparency has undermined important values such as trust, responsibility and true accountability. The removal of the mystery of judicial appointments by detailed regulation in the Constitutional Reform Act 2005 would probably meet with her disapproval. (I must say that I see something very worrying in the assurance in $\mathrm{s} 1$ of that Act that nothing in the statute adversely affects the rule of law!). For others, an insistence on openness and access to 
information is self-defeating. As Jean Jacques Rousseau (quoted in Hood 2006) expressed the point:

'Books and auditing of accounts, instead of exposing frauds, only conceal them; for prudence is never so ready to conceive new precautions as knavery is to elude them.'

I have never made the case for access to information as an unqualified human right. Of course there are justifiable limits to access to government held information. But I remain a firm believer in FoI laws and I argue elsewhere that freedom of information is a human right (Birkinshaw in Hood (2006) and Administrative Law Review (2006) forthcoming). The problem is the old constitutional conundrum. Who decides on who decides: in this context where the limit on FoI is?

The thesis is that governmental power is ultimately in its most important reaches not subject to effective legal constraint. It is simply beyond law's empire. Had the decision of the Court of Appeal (A etc v Secretary of State [2004] EWCA Civ 1123) allowing information allegedly extracted by torture to be used by the Home Secretary not been reversed by the Law Lords, there would have been little effective restraint on how the government obtains and uses information for intelligence provided it was obtained without use of British officials overseas. The Law Lords have at least ruled such evidence inadmissible in judicial proceedings ([2005] UKHL 71).

Quite what impact this will have on intelligence gathering we will have to wait and see. But there is a twohandled dimension to this: government may not be able to use the law to protect its secrets when that need for secrecy is felt to be at its greatest. This is vividly illustrated by the acquittal of Clive Ponting over 20 years ago, an acquittal that led to the reform of the 1911 Official Secrets Act and the replacement of the blunderbuss with the armalite when a jury refused to convict as enjoined by the trial judge, Attorney General and members of the government.

The jury saw its constitutional duty in acquittal. It was graphically illustrated in 2004 by the powerlessness of the Attorney General to initiate criminal proceedings to punish Clare Short and a junior official over leaks concerning bugging and tapping activities of British intelligence services at the UN HQ.

I shall concentrate on the following points:

1. The structure of the FoIA.

2. The war on terrorism

3. International and diplomatic relationships

4. Illegitimate use of privacy

5. Commercial secrecy and the public interest

6. Access to information and openness as a human right

\section{A BRIEF OVERVIEW OF FOI}

Before that, allow me briefly to describe the information society that we have become. We are all familiar with the litany of benedictions concerning the bright side of FoI in domestic and EU laws. Here is one example from Europe:

The evolution towards an information and knowledge society influences the life of every citizen in the Community .. by enabling them to gain new ways of accessing and acquiring knowledge. (Directive 2003/98/EC Re-use of Public Sector Information).

Let me start by saying that the experience of FoIA UK so far has very promising features although the delays by some public authorities in responding to requests are worrying. The decision in relation to fees was a good one in stipulating that up to limits ( $£ 600$ for central government, $£ 450$ otherwise) fees will not be charged for information. The right is a right to information, but where access to documents is the best way of fulfilling this right, provision of documents should be allowed. The public interest test is weighted in favour of disclosure. One hundred thousand public authorities are covered including Parliament. The Act (which came into effect on January 1, 2005) is fully retrospective. The Act is not so generous in its protection of classes of information and the test of prejudice or damage to withhold specific information is not as generous as the Scottish legislation which opted for "substantial prejudice" in most cases.

The Government refused to impose a duty on authorities to provide indexes of documents held but we now have publication schemes and inforoute provides direct access to the Government's Information Asset Register (IAR). The Office of e-Envoy states that:

"The IAR lists information resources held by the UK

Government, concentrating on unpublished resources. In

doing so it enables users to identify, from one single source,

the information held in a wide variety of government

departments, agencies and other organisations. Inforoute is a

key part of the Government's agenda for freeing up access to official information."

Under the 2005 Re-use Regs, public authorities (PAs) are encouraged to produce IARs to comply with that regulation which seeks to facilitate use of public sector information by private bodies. An information asset is any information item that a public sector body produces that is of interest or value to the organisation itself, and potentially to others.

There is a fever of activity and proliferation of consultancies concerning FoI. A great deal that has come to pass is constructive and McDonald has set this out in a paper in Hood's book (McDonald, 2006). We are bombarded by information: Performance Indicators; statistics; publication schemes; an Information Commissioner and Tribunal, Information officers, Office of Public Sector Information; National Archives, National 
Statistics and in most cases devolved analogues. Communications technology has increased the pressure for open source. It is calculated that there are nine million pages of UK government domain (.gov.uk) (Margetts (2006).

With the development of so much information and communications technology (ICT) the spectre has grown of intellectual property rights and the pretence of using copyright protection to avoid FoIA. The Department for Constitutional Affairs (DCA) guidance on disclosure and copyright is correct but incomplete and misleading. But the Copyright etc Act 1988 is quite clear. Section 47 exempts from copyright "material" open to public inspection pursuant to a statutory requirement (arguably FoIA) which contains factual information. It contains a good many other provisions protecting such material from copyright infringement. Section 50 Copyright etc Act concerns acts done under statutory authority: "Where the doing of a particular act is specifically authorised by an Act of Parliament, whenever passed, then, unless the Act provides otherwise, the doing of that act does not infringe copyright" (s50(1)). FoIA does not provide otherwise and specifically authorises disclosure. In short, this provision covers documents held by public authorities or produced by public sector employees in and for their employment even where the copyright is sold to another body.

One brief example of the improved culture concerns a body that I have worked with for five years. Nirex UK is a company owned by government that advises on the disposal of nuclear waste. Since 1999 it has engaged in efforts to improve transparency and access to information leading recently to the naming of 12 former possible sites suitable for deep disposal of nuclear waste - actually the original list was 537! For several years government policy had been against disclosure of this list. The Nirex transparency panel - established under Nirex's transparency policy to hear complaints against refusal of requests for access to documents under the Nirex code on access to documents - had in successive years recommended disclosure of this list. In the spring of 2005, Nirex released the information. Nirex released the list in a managed and responsible fashion after an EIR request. The views of the transparency panel had a pronounced impact and a great deal more information beyond the site list was published.

I must return to my list of problem areas.

\section{THE STRUCTURE OF THE FOIA}

McDonald has said that FoIA was not giving answers like a Finance Act which stipulates rates of tax: it was providing new rules on how the citizen/state relationship was to be conducted (McDonald 2006). Until 2005, there had been a statute for local government; non-binding codes existed for central government and health bodies supervised by the Ombudsman (HC 59 and 61 (2005-06)). In relation to central government there had been worrying tendencies not to disclose information despite recommendations for disclosure by the Parliamentary Ombudsman - particularly in the Cabinet Office and DCA. When the FoI Bill came it was structured around Data Protection legislation and the select committee which I advised was committed to persuading government to elide provisions that were unsuited to FoIA. In some cases the Committee was successful. A veto exists in section 53 to overrule the Information Commissioner's notices on access - a promise was given that a veto would be exercised after a collective decision by the Cabinet and not by a single Ministerial veto. The precedent for a collective veto came from New Zealand where after that safeguard was introduced no vetoes were issued. On the day FoIA came into effect (1 January 2005) Lord Falconer promised that the power of veto would be rarely used- it would be "very very exceptional". Judicial review is the only means of challenging a veto.

Some limits in FoI practice are extra-statutory. A clearing house has been established in the DCA to achieve consistent responses and provide guidance on difficult cases. Some see otherwise and have noted the tendency for centralised control to slow down response times. There is an informal agreement between the Information Commissioner and DCA on how to handle sensitive information and which appears to limit the IC's access to information after a section 50 notice where access by the IC "is not necessary" (para 12). There are eight absolute exemptions - understandable in most cases because the information is available by other means or disclosure is prohibited by law although I shall say more about security in a moment. The breadth of some of the ordinary exemptions including criminal investigations and law enforcement (ss.30 and 31) and commercial interests is staggering but these are subject to public interest tests.

Other provisions of the legislation denying access especially in the policy making process (s 35) and disclosure which would otherwise prejudice the effective conduct of public affairs (s 36) have the potential to retain maximum secrecy for the governmental process. It reminds one of the words of Lord Wilberforce in earlier litigation who deplored the criticism "of the inner workings of government while forming important governmental policy" by otherwise ill-informed members of the public (Burmah Oil v Bank of England [1979] 3 All ER 700 at $707 \mathrm{~g}$ ). The world has moved on from almost 30 years ago although the sensitivity of government has not, it seems.

\section{THE WAR ON TERRORISM}

FoIA excludes the secret intelligence and security services from its provisions. Information supplied by or relating to these bodies in the possession of other public authorities is given an absolute exemption. Decisions on national security exemptions are challengeable by appeal to the 
information tribunal. At the EU level the use of security classifications has been notable as a means of exclusion from access and for the non-registration of documents in otherwise publicly accessible registers.

Information may be withheld indirectly and not simply by refusing access to information. This is achieved by denying any opportunities for challenge to decisions concerning others' rights or liberties. The emphasis here is on secretive processes. Some examples of secrecy have included: the legal black hole of Guantanemo as Lord Steyn and Lord Phillips described it whereby the US government sought to remove from the jurisdiction of US civil courts the cases of those imprisoned on US owned property in Cuba. The question of the powers of detention by US and British authorities was raised; the detentions involved those held by the Americans at Guantanemo and also US citizens held under military powers in the USA. In the case of Britain, the detentions concerned those under the Antiterrorism, Crime and Security Act 2001, section 23 in the UK, and detentions (of Iraqis - one at least being also a British national) by occupying forces in Iraq. In the USA the notorious pictures of enforced bestial and simulated sodomy by prisoners under the constraint of US forces were published after US FoI requests.

In terms of detention the differences between the two jurisdictions is stark. In the USA, while habeas corpus was applicable to challenge detentions under US legislation both by American citizens and aliens (a Bill has passed the Senate to reverse the latter), the Supreme Court has ruled by majority that there is little the courts can do - even if it means formulating the executive's case for detention in the absence of reasons by the executive because of the inadequacy of the grounds put forward by the executive. This was deprecated by Scalia J who while he portrayed a common law fundamentalism leaning heavily on old English as well as US precedents in rejecting the President's case for detention nonetheless drew a distinction between aliens and US citizens and their respective protection under US law. (Hamdi v Rumsfeld 542 US 507; Padilla 72 USLW 4584 and USCA 9/9/05 and Rasul v Bush 72 USLW 4576). This should be compared with the decision in A v Secretary of State (Belmarsh) where the case for detention was rejected overwhelmingly by the House of Lords and where drawing a distinction between nationals and aliens was unlawful under the Human Rights Act (HRA). I say more about $A$ below. It was also the occasion when the Attorney General labelled judicial intervention in such matters as "undemocratic" a criticism roundly rebutted by Lord Bingham ([2004] UKHL 56 para 42).

A critical development in the US was the post 9/11 revision of FoIA by the Homeland Security Act and Critical Infrastructure Information Act covering much of relevance (but not all) to recent hurricanes and the ill-prepared state of authorities and contractors. Before that revision, the emphasis on secrecy had been seen by the US Attorney
General's memo in 2000 advising departments and agencies on FoIA requests and a presumption of non disclosure rather than disclosure as in Clinton's administration. There were also the revised Presidential executive orders classifying and reclassifying information as secret. In the UK, the cause celebre was the refusal to publish the full story behind the UK Attorney General's advice on the legality of the Iraq war. After a leak to the press, the government released the advice which only raised further questions about the full context of the advice and which led to further appeals to the IC.

The use of special advocates by the UK in deportation appeals and their spread to non-terrorist if serious criminals (Roberts v Parole Board [2005] UKHL 45) has witnessed erosion of procedural protection for those suspected of terrorist connections and the procedure now covers the Parole Board. A specially appointed and vetted advocate would represent the appellant before the Special Immigration Appeal Commission (SIAC) or the Parole Board, in the absence of the appellant and his legal representatives, at a closed hearing before the tribunal. Lord Bingham continues and I quote extracts from his judgment:

'The Board will receive and be free to act on material adverse to the appellant which will not, even in an anonymised or summarised form, be made available to him or his legal representatives. Both he and his legal representatives will be excluded from the hearing when such evidence is given or adduced .. The Parole Board assert that the specially appointed advocate may call witnesses. This was not, however, the understanding of the House of Commons Constitutional Affairs Committee (HC 323-I (2004-05) para 52(iii)). But even if a specially appointed advocate is free to call witnesses, it is hard to see how he can know who to call or what to ask if he cannot take instructions from the appellant or divulge any of the sensitive material to the witness.... In the vivid language used by Lord Hewart CJ .... the speciallyappointed advocate would inevitably be "taking blind shots at a hidden target". ' (Para 18)

Lord Bingham found the procedure in the case of the Parole Board infringed the common law of natural justice and Convention jurisprudence and was unlawful. Together with Lord Steyn they formed the dissenting minority judgments.

The possible extension of the special advocate procedure to public interest immunity claims in criminal cases was discussed in $R_{v} H$ ([2004] 1 All ER 1269). The "problem" of public interest immunity was one that emerged from the overruling of the House of Lords judgment of Duncan v Cammel Laird (1942) in Conway v Rimmer (1968). In Conway, the judges for the first time ruled that they could look behind a certificate, ministerial or otherwise, claiming immunity for documents. We were witnessing the development of the law of Public Interest Immunity in civil litigation - one of the less celebrated 
progenitors of modern English administrative law and a central feature in the Dual Use Equipment for Iraq (HC 115 (1995-96) inquiry nearly ten years ago. In Conway, the Law Lords refused to accept the ipse dixit of the responsible officer who wished to prevent the adversary in litigation gaining access to documents in his authority's possession or where a responsible official wished to resist disclosure which it was alleged would otherwise be against the public interest (Birkinshaw 2005, ch 10). The plea is common now in criminal trials and a recent statement from the Attorney General to prosecutors has criticised the plea's excessive use by defence lawyers in such trials.

In terms of secreting processes, the following is instructive. The "shoot to kill" policy put to dramatic use in London in the summer of 2005 was not discussed with the police authority; nor was it discussed in Cabinet but only with a few senior Ministers. (Lord Stevens former Metropolitan Police Commissioner 19/9/05 Radio 4 Today Programme interview with John Humphries). The obsession with security is understandable. But is it necessary to have secretive processes of government in which life or death policies are not even discussed at Cabinet level? It is a throw-back to an age old and disreputable tradition.

\section{INTERNATIONAL RELATIONSHIPS}

The problems here are multi-dimensional but I concentrate on two. The absence of global provisions on access to information and the secrecy and sensitivity of diplomatic relationships. Secondly, the confusion of national and international legal standards and regimes.

Arguments for transparency in world affairs have an ancient and distinguished lineage. These include Kant's arguments against secret treaties in Towards Perpetual Peace (1795); Woodrow Wilson who wished for "open covenants of peace openly arrived at with no secret international agreements in the future". Negotiations, he noted, would be in private, however. I have argued elsewhere for global transparency (McCloud and Parkinson 2006). Specific treaties may provide information on GATT/WTO, nuclear non-proliferation, environmental pollution, torture and child labour. A leading example is the Arhus Convention ( $\mathrm{Cm}$ 4736) concerning access to environmental information, participation in environmental decision making and access to justice which has been implemented into domestic law by SI 3391/2004 (and Scottish equivalent). A common position on a regulation covering access to environmental information held by EU institutions has been agreed (2005/OJC 264 E/18: 25/10/2005).

But companies (transnational corporations) and NGOs operate in global markets where there are inadequate rights of access to information internationally (the UN itself has no such law) or, in many cases, domestically. Al Roberts has shown how US influence in NATO has forced Official Secrecy laws on Eastern European states escaping from oppressive Communism although in some cases secrecy was opposed (Roberts 2003). Diplomatic and international sensitivity is notorious. It can be seen in the Court of First Instance in the EU which has given several recent judgments interpreting very restrictively regulation 4(5) of the EU access Regulation (1049/2001): in particular the IFAW decision ([2004] T-168/02) concerning environmental documents passing from Germany to the Commission and Germany's request not to disclose the documents. Under regulation 4(5) a "member state may request the [EU] institution not to disclose a document originating from that member state without its prior agreement." That "request" was a determination and was final and conclusive, the CFI ruled (also noteworthy is Mara Messina [2003] T-76/03). This seems to go too far. The Council relies upon international relations and security as the major reason to deny access to documents under the Regulation.

The internationalisation of domestic law was dramatically illustrated by the judgments in Pinochet ([1998] 4 All ER 897; [1999] 2 All ER 97 (HL)) even if the final position adopted by the Law Lords was not as epochal as their first aborted judgment. Those accused of torture and war crimes while they were heads of state increasingly face the prospect of domestic proceedings in foreign jurisdictions. Internationally agreed standards are having a direct impact in domestic legal systems. The UK's international relations are coloured by our membership of the EU and ECHR. Domestic courts are bound by decisions of the EU courts under sections 2 and 3 European Communities Act 1972 and they must have regard to the jurisprudence of the Court of Human Rights by virtue of the Human Rights Act, section 2. The power of the former was seen conclusively in Johnstone $v$ Chief Constable RUC ([1986] 3 All ER 135). A ministerial certificate seeking to prevent a tribunal dealing with an allegation of sex discrimination in the RUC on the grounds of public order/national security was overridden by the ECJ because it denied access to justice - the first time such a certificate enforcing closure for security had been defeated.

The power of the Convention and the HRA have been witnessed in case law concerning detention of alleged combatants in Iraq by British forces and the holding of the court (subject to appeal) of the extraterritoriality of the HRA and its application to those detained by British forces in Iraq (Al-Skeini [2005] 2 WLR 1401). This was followed by a decision which examined the nature of rights under the Convention as incorporated under the Human Rights Act. Such rights are subject to superior norms of international law - in this case UN Security Council Resolution 1546. The antipathy of English law to rule by prerogative by the Crown was aimed partly at the prevention of international treaties (an act of prerogative) overriding the common law and statute (for a classic abuse of prerogative power to dispense with laws, see: Godden $v$ Hales (1686) 11 St Tr 
1165). We have witnessed the resort to international norms to enhance the rights of individuals. What this case represents is the spectre of international law concerning occupying forces overriding the UK Human Rights Act and its protection for British citizens (Al Jedda [2005] EWHC 1809 Admin). The solution adopted in the High Court may be one of convenience because of the multi-national nature of the occupying forces (and is subject to appeal) but a contrary argument is that it is four hundred years too late to non-suit the Case of Proclamations (1611) 12 Co Rep 74) and its ruling on the illegality of legislation by prerogative to amend the general law.

\section{IMPROPER USE OF PRIVACY}

Privacy - or protection of private personal information - is a human right. That is now a statement of British and Northern Irish law (Campbell v Mirror Group Newspapers Ltd [2004] UKHL 22). It is an area in which the British judges have been profoundly influenced by the jurisprudence of the CHR. But we have to be careful that laws made or developed to protect individual integrity are not abused to make government "all inside and no outside". The problem arises when privacy is used unjustifiably to deny access to information. For example, names cannot be released of officials performing public duties, or payments to officials, or actions involving officials, or of individuals meeting officials because allegedly of Data Protection laws. The position is not assisted by the complexity of DP legislation and judicial interpretations of key terms (Durant v Financial Services Authority [2004] EWCA Civ 1746).

The problem focuses upon the relationship between access and secrecy in UK laws: the courts have engaged in difficult balancing exercises in relation to the legitimate requirements of respect for privacy and freedom of expression of the press. But our laws on access and data protection were drafted to give predominance to DP over FoI in the FoIA section 72. The EU has also witnessed difficulties in this area with refusals by the Commission to give names in many circumstances. The EU Ombudsman has criticised what he considered incorrect use of data protection (see 2004 AR pp.45-46). In July 2005, a paper from the European Data Protection Supervisor (Public Access to Documents and Data Protection (July 2005)) criticised unjustifiable resort to data protection to maintain secrecy in public life. Data protection was about privacy protection in private life.

There may be occasions when protection of identities involving public duties is necessary for reasons eg of personal safety. The UK Information Commissioner has already made several decisions in this area. Several have protected privacy for understandable reasons: protection of informers' identities, or the identities of officials where there was no good reason to reveal identities (and qualifications). But data has been released where it involved payment of monies to a senior employee and under FoIA details of individual payments under the CAP have been allowed. The IC has used a judicious application of Schedule 2 paragraph 6 Data Protection Act to circumvent unjustified barriers. There is of course a proper place for privacy protection. The proposed law on identity cards is criticised for unnecessary expense and for being the most centralised and extensive collection of personal data ever seen in the UK - a regime that critics argue lacks adequate safeguards for privacy.

\section{COMMERCIAL SECRECY AND PUBLIC INTEREST}

There is an ever-greater reliance on contractual arrangements for delivery of public services. Public procurement laws from the EC have sought to instil greater transparency in public purchasing. The FoIA may apply directly to contractors who are designated by order where they exercise functions of a public nature or who provide under contract with a public authority (PA) "any service whose provision is a function of that PA" (s 5(1)(a)(b)). The Office of Government Commerce has provided guidance on contracting and public purchasing and FoIA requirements. FoIA is not silent on these issues. Section 43 exempts trade secrets or disclosure which would, or would be likely to, prejudice the commercial interests of any person (including the PA holding it). Section 41 protects information provided in confidence where disclosure would constitute an actionable breach of confidence. The latter is an absolute exemption.

The law of confidentiality has its own public interest test in disclosure which negates the duty of confidence. The code of practice under FoIA section 45 provides advice and guidance on confidentiality and this was watered down in various stages of publication before it was approved by Parliament. Confidentiality clauses, it originally advised, should only be used "exceptionality"; now "PAs should bear clearly in mind their obligations under the Act when preparing to enter into contracts which may contain terms relating to disclosure of information by them." The Code on EIRs is stronger and rather like the original section 45 draft.

There are obiter dicta to the effect that contractual duties of confidence are stronger than equitable ones $(A G \mathrm{~V}$ Parry [2004] EMLR 13). Surely, confidentiality can only protect that which is confidential and not information which does not deserve to be identified as "confidential". Some useful guidance is given by Robert Walker $\mathrm{LJ}$ in $L R T$ $\checkmark$ Mayor of London ([2003] EMLR 4). This case concerned publication of criticism about a proposed Public Private Partnership (PPP) arrangement on London Underground. Attempts were made to use commercial confidentiality to protect an interim report prepared by a firm of accountants based on commercially confidential information. This had been submitted by private sector bidders subject to express confidentiality agreements. 
'The guiding principle is to preserve legitimate commercial confidentiality while enabling the general public (and especially the long-suffering travelling public of London) to be informed of serious criticism from a serious source of the VFM evaluation which is a crucial part of the PPP for the London Underground.' (Para 50)

In his supporting judgment, Sedley LJ stated that Art 10 ECHR concerning freedom of expression - which came into play (and therefore s 12 HRA which seeks to prevent gagging injunctions and see Cream Holdings [2004] UKHL 44 ) is not just about freedom of expression. "It is about the right to receive and impart information .. the life-blood of democracy" (para 55).

Third party challenge to PFI/PPP arrangements have proved difficult - these are mostly negotiated and so fall within the least demanding of transparency requirements of procurement regulations. We have seen above how private bodies may be designated as 'public'. That brings us to the enduring problem of the horizontality of public power: a point that has arisen in judicial review and in human rights litigation. The subject concerns the appropriateness of binding private actors doing government business to public law standards. If given too much rein, commercial secrecy could blanket what are really government duties owed to the public. Commercial confidentiality and interest are exemptions that can lend themselves to abuse. The watering down of the guidance has been referred to. Without adequate supervision the exemptions could prove particularly attractive as we move to more government by contract or public private partnerships. This was partly why the US government sought approval of the Critical Infrastructure Information provisions in the Homeland Security Act so that information from private contractors would be excluded from US FoIA.

\section{ACCESS TO INFORMATION AND OPENNESS AS A HUMAN RIGHT}

There is no provision within the ECHR on access to information. There is a Recommendation of the Council of Ministers from 2002(2) on access. The ECHR and HRA have inspired interesting developments even if the decision in Shayler ([2002] 2 All ER 477 (HL)) showed that section 1 Official Secrets Act 1989 providing absolute duties of secrecy on security and intelligence officers is consistent with Article 10. The important impact here has been the decisions of the Court of Human Rights (CHR) on Articles 2 (right to life), 6 (fair and open trial), and 8 (right to private and family life) in particular and how these have been used to establish a right to information and independent supervision of that right (Oneryildiz 39 EHRR 12; Edwards 12 BHRC 190; Gaskin 12 EHRR 36; Guerra 26 EHRR 357. The CHR has accepted that Article 10, which guarantees a right to freedom of expression and to pass on information, does not provide an access to information right (McGinley 27 EHRR 1). The meaning of freedom of expression will be tested in the Inter American Court on Human Rights for the first time in relation to access to information. Article 13 IACHR (a free speech provision) has been invoked to provide an access right to state held information. The litigation concerns a refusal by Chile to provide information about inward investment and its environmental impact. (Case 12.108 Claude Reyes et al $\mathrm{V}$ Chile July 2005 www.justiceinitiative.org)

The jurisprudence of the CHR, and its limitations, have obviously had their impact on domestic law. In Wagstaff ([2001] 1 WLR 292) the inquiry into the Shipley murders had to be held in public after Article 10 was invoked. But in Persey ([2003] QB 794) concerning the foot and mouth inquiry Article 10 did not provide such a right. Wagstaff was not followed in Howard ([2003] QB 830). Art 10 has also been interpreted in England to provide a right not to be prevented from speaking: it does not confer a right of access to a broadcaster ( $R$ (Pro-Life Alliance) v BBC [2003] 2 All ER 977 (HL)). The Article 2 case law has shown a judicial willingness to allow open inquiries after racist murders in prison $R$ (Amin) v Secretary of State [2003] 4 All ER 1264 (HL) or fatalities following medical treatment ( $R$ (Khan) v Secretary of State [2003] 4 All ER 1239). There is also a substantial case law on how failure to provide adequate reasons on the achievement of the objectives of an inquest amounted to a breach of Article 2 (Birkinshaw 2005 para 9.147). This leads on to the next point:

I have argued elsewhere that FoI is a human right. Like all human rights - and even now torture it seems - it is not absolute. Our governors, despite piloting the HR Bill through Parliament, do not take human rights seriously; they are not seen as trumps for the weak and unpopular. There have been heavy hints from the government on the introduction of legislation to guide judges in the interpretation of the substance of human rights and how they should be weighed against the requirements of national security. The EU Charter of Rights contained guidance on the interpretation of the rights within the Charter (to prevent some of them becoming "rights" once they are made a legally binding part of the EU Constitution). What is to be gained by declaring the right to FoI as a fundamental right? Even within the constraints imposed by the incorporation of the ECHR, the acknowledgment of FoI as a human right would give the balance to openness and access making them rights of equal status to freedom of speech, the right to life, the right to privacy. But how would this be achieved? A treaty on FoI has been urged upon the Council of Europe: $<$ http://www.justiceinitiative.org/db/resource2?res_id $=1$ 02667>

Amendment of the Convention would appear unavoidable, but at present an unlikely prospect. The alternative would be common law recognition of such a right. But would the courts abandon their reluctance to assume the role of advocates of open government? An examination of the case law shows that the courts have 
already made a significant contribution to making government more open.

\section{INFORMATION AND LEGAL ARGUMENT}

In litigation evidence is a central feature of litigation. Evidence is information. Rules test its admissibility and judicial guidance is given on reliability. The FoI culture is having an impact on litigation. It falls to the applicant/plaintiff/claimant to prove their case. Judicial review is not a trial and there is an understandable reluctance to make it such - it is a speedy process of review. Judicial review changes in procedure were introduced under Part 54 CPR (Birkinshaw 2005 chs 9 and 10); human rights litigation often involves questions of necessity/proportionality; the arguments must be better reasoned and more fully supported by authorities. More evidence is required. Fair procedure allowing hearings is being ever extended: see the House of Lords judgment on the duty to hold an oral hearing involving a prisoner whose licence is revoked (Regina v Parole Board ex parte Smith [2005] UKHL 1). The law presses for this. It is producing conflict between the judges and the government as the executive claim their terrain is invaded. It is one of those reasons for embarking on constitutionalism: fear of the many and fear of the few.

The government fear is that of the few and unelected judges judicialising the political process. Judges who are, under the terms of governing legislation and in various ways extending the concept of the polity. The latter is another timeless feature of the route to constitutionalism: what is the polity? HRA gives it a broad answer as does FoIA.

The doctrine of proportionality has made a vital difference. Its application or non application are often, but not always, crucial for outcome: see for instance the $R$ (ProLife) v $B B C$ case and the differing decisions of the Court of Appeal and House of Lords ([2002] 2 All ER 756 and [2003] UKHL 23). Proportionality is a vital factor where human rights are engaged. Lord Steyn's judgment in Daly ([2001] UKHL 26) is well known on this point but see Sedley LJ in London Transport above. The balance of competing rights (confidentiality and disclosure), he said:

Lies in the methodological concept of proportionality.

....Does the measure meet a recognised and pressing and social need? Does it negate the primary right or restrict it more than is necessary? Are the reasons given for it logical?

... for my part, I find it more helpful today to postulate a recipient who, being reasonable, runs through the

proportionality checklist in order to anticipate what a court is likely to decide, and who adjusts his or her conduct accordingly. (paras 57-58)

What limits are placed on this process? The judges themselves have resorted to the separation of powers. The judges should not meddle in matters over which they have no expertise. This is clearly illustrated by the decision in
Rehman ([2002] 1 All ER 122 (HL)). In Rehman the appellant faced deportation because his presence in the UK was deemed not conducive to the public good in the interests of national security. He was accused of engaging in various terrorist training activities aimed at overseas countries. The appeals commission (SIAC) overruled the Home Secretary on the grounds that he had asked the wrong questions in determining national security - he had made an error of jurisdictional fact. Furthermore ruled SIAC, the Home Secretary had to be satisfied of wrongdoing on a "high balance of probabilities".

The real issue said Lord Hoffmann was not what Rehman had done but on the basis of the case as a whole whether the Home Secretary was entitled to consider that R's presence was a danger to national security. "In the interests of national security" is not a straightforward question of law - unlike "national security" - but an issue of "judgment and policy" entrusted to the executive (para 50). It is artificial to separate national security from foreign policy; the latter is clearly a matter for the executive. The Home Secretary must have a factual basis for his assessment but the Commission's ability to differ must be limited by the appellate function (para 54). The concept of standard of proof is not appropriate - the question is not whether something happened but the extent of a future risk. "Each allegation cannot be taken seriatim and asked whether it was established to some standard of proof. It is a question of evaluation and judgment" (para 56).

SIAC, continued Hoffmann, is not the primary decision-maker. The decision is entrusted to the Home Secretary who "has the advantage of a wide range of advice from people with day to day involvement in security matters which the commission cannot match. It involves an evaluation of risk .. to which the primary decision maker is owed a wide margin of respect." Basically, SIAC should not interfere with a range of decisions at which the Home Secretary may reasonably arrive (para 57). SIAC lacks the expertise. But it does possess broad powers of appeal including reversing a discretion of the Home Secretary. The respect for the executive function was shown in the Belmarsh decision (though strangely not by Lord Hoffmann) when the majority ruled that the declaration of a public emergency leading to a derogation from the Convention was not unlawful. It was within the executive's (and legislature's) margin of discretion and was preeminently a "political judgment". Courts had to respect the "relative institutional competence" and recognise their limits. Similar diffidence did not apply to the measures taken to detain the suspected terrorists as we have seen above or to rule on the inadmissibility of intelligence extracted by torture in judicial proceedings.

\section{CONCLUSION}

Government constraint on information used to be not unlike God's prohibition on eating from the fruit of the forbidden tree. Partake and there will be damnation and 
catastrophe. It was for our superiors to decide: was disclosure "kind, wise and necessary"? The response was limited. But the world has changed and erstwhile responses and justifications are no longer adequate. New justifications for secrecy, as well as for advancing the democratic engagement have to be given. No-one can deny that disclosure of information can be a terribly dangerous thing - on informers' identities; on access to scarce and irreplaceable resources which will be pillaged for profit, on security information to enemies of the state. The trouble is in all the cases I examined above the decision on secrecy is ultimately government's. Challenge in sensitive areas is difficult, if not impossible. Or a problem results from indecision and failure by governments to act appropriately in relation to FoI as in the international arena.

Governments often have an interest in not disclosing information: sometimes selfish and corruption concealing; more often for reasons of political expedience: to stay in office; to have the advantage over political opponents. I cannot help but think there is a continuum of that "crisis" mentality that introduced the Official Secrets Act 1911 s.2 in our present frenetic activities concerning security. I am conscious of the dreadful scenes that shocked the world only yards from where this lecture was delivered and the frightening spectre of suicide bombers who were British born and bred and not a feature of frightening mayhem from afar. But in the protection of our civil liberties and human rights we still have to be very careful that political overreaction does not place a wide national security blanket over our newly emerging openness. We should also seek to remove some of the deficiencies in the FoIA and DPA. But at least we do have a FoIA. And I believe we are better for that.

\section{REFERENCES}

P. Birkinshaw (2001) Freedom of Information: the Law, the Practice and the Ideal Lexis/Nexis/Cambridge University Press 3rd ed.

P. Birkinshaw (2005) Government and Information: the Law Relating to Access, Disclosure and their Regulation Tottel Publishing 3rd ed.

P. Birkinshaw (2006) in Hood (2006).

P. Birkinshaw and A. Parkin (1999) in Constitutional Reform eds Blackburn and Plant, Addiscon, Wesley and Longman.

C. Hood Transparency: the Word and the Doctrine (2006) British Academy, forthcoming.

H. Margetts in C. Hood above.

A. McDonald in C. Hood above.

S. MacCleod and J. Parkinson (2006) Global Governance and the Quest for Justice Vol II Hart Publishing, forthcoming.

A. Roberts (2003) in National Security and Open Government: Striking the Right Balance Campbell Public Affairs Institute, the Maxwell School of Syracuse University pp. 147 et seq.

\section{Patrick Birkinshaw}

Professor of Law, Hull University; Barrister

(C) Patrick Birkinshaw

November 2005 